\title{
Health diagnosis: a responsibility of community health nursing in Angola
}

\author{
Diagnóstico de saúde: uma responsabilidade da enfermagem comunitária em Angola \\ Diagnóstico de salud: una responsabilidad de la enfermería comunitaria en Angola
}

\section{Carla Alexandra Silva', Elsy Oliveira Tavares', Teresa Sousa Pinheiro', Helena Maria Guerreiro José' \\ 'Instituto Superior Politécnico de Saúde Multiperfil. Luanda, Angola.}

\section{How to cite this article:}

Silva CA, Tavares EO, Pinheiro TS, José HMG. Health diagnosis: a responsibility of community health nursing in Angola. Rev Bras Enferm [Internet]. 2018;71(5):2506-10. DOI: http://dx.doi.org/10.1590/0034-7167-2017-0610

\section{Submission: 09-13-2017_Approval: 11-09-2017}

\section{ABSTRACT}

Objective: To characterize the health situation of the population in the Imbondeiro neighborhood, sector C (Luanda). Method: This is a descriptive, cross-sectional and quantitative study. Families living in the sector were included, included in the sample by "door to door" contact. They accepted to participate through a free and consented form. Results: Health diagnosis of 341 family households was conducted, involving 1,312 people. A total of $46.02 \%$ are male and $54.08 \%$ are female; from these, $42.62 \%$ are children, $15.14 \%$ adolescents and $42.24 \%$ adults. Conclusion: The results obtained and presented are in accordance with the data from the National Institute of Statistics of Angola (INE), revealing that it is necessary to intervene and to promote healthy lifestyle habits, regarding issues such as domestic violence, alcohol consumption, inappropriate eating habits, sexually communicable diseases, among others.

Descriptors: Diagnosis; Health Promotion; Primary Health Care; Social Determinants of Health; Community Participation.

\section{RESUMO}

Objetivo: Caracterizar a situação de saúde da população do bairro do Imbondeiro, setor C (Luanda). Método: Estudo descritivo, transversal e quantitativo. Incluídas as famílias residentes no setor, que aceitaram participar de forma livre e esclarecida e acedidas de modo acidental, por contacto "porta a porta". Resultados: Fez-se o diagnóstico de saúde de 341 agregados familiares, envolvendo 1321 pessoas. 46,02\% são do género masculino, 54,08\% do género feminino; destes, 42,62\% são crianças, $15,14 \%$ adolescentes e $42,24 \%$ adultos. A maioria das famílias é alargada. A alimentação engloba açúcares e hidratos de carbono. Existe consumo de álcool e violência. Conclusão: Os resultados obtidos e apresentados vão de encontro aos do Instituto Nacional de Estatística (INE), no que diz respeito às três faixas etárias estudadas e ao seu diagnóstico de situação de saúde, revelando ser necessário intervir na promoção de hábitos de vida saudáveis, em áreas como violência doméstica, consumo de álcool, hábitos alimentares, doenças sexualmente transmissíveis, entre outras.

Descritores: Diagnóstico; Promoção da Saúde; Atenção Primária à Saúde; Determinantes Sociais de Saúde; Participação da Comunidade.

\section{RESUMEN}

Objetivo: Caracterizar la situación de salud de la población del barrio Imbondeiro, sector C (Luanda). Método: Estudio descriptivo, transversal, cuantitativo. Se incluyeron las familias residentes en el sector, que aceptaron participar de forma libre, aclarada, a las cuales se tuvo acceso de modo accidental, por contacto «puerta a puerta». Resultados: Se realizó el diagnóstico de salud de 341 agregados familiares, lo que implicó a 1321 personas, de las cuales un 46,02 \% del sexo masculino y un 54,08 \% del sexo femenino. De estos, un 42,62 \% son niños, un 15,14 \% adolescentes y un 42,24 \% adultos. Conclusión: Los resultados obtenidos y presentados están de acuerdo con los datos del Instituto Nacional de Estadística, lo que revela la necesidad de intervenir en la promoción de hábitos de vida saludables, en cuestiones como violencia doméstica, consumo de alcohol, hábitos alimentarios inadecuados, enfermedades sexualmente transmisibles, entre otros.

Descriptores: Diagnóstico; Promoción de la Salud; Atención Primaria de Salud; Determinantes Sociales de Salud; Participación de la Comunidad. 


\section{INTRODUCTION}

Angola is going through an epidemiological transition, characterized by the impact of communicable diseases and non-communicable chronic diseases, and, despite the investment made and the improvement of the main country's global health indicators, they are still below the average of the African countries and other countries in the world ${ }^{(1)}$. There is high maternal, infant and infant-juvenile mortality rates, high degree of malnutrition in children under 5 years, persistence of cholera, rabies and measles, as well as an exponential increase of road accidents and violence ${ }^{(2)}$. Given this, a greater focus is required on measures of health promotion and protection, disease prevention, social information and mobilization to obtain a higher empowerment and participation of communities in health interventions ${ }^{(1)}$.

According to data from the 2014 Angolan Censuses, a total of $25,789,024$ inhabitants were registered $-48 \%$ were male and $52 \%$ female, with a natural population of growth rate $2.7 \%{ }^{(3)}$. Out of these, $63 \%$ live in urban areas and $37 \%$ in rural areas, being the Luanda province the most inhabited with 6,945.386 residents ${ }^{(3)}$. The ratio of the population aged from 0 to 14 years is $47.3 \%$ and of seniors is $2.4 \%$ - it noteworthy that only $13 \%$ of the population between 18 and 24 years completed the II Cycle of Secondary Education $^{(3)}$. These data reflect a quite young population, situation very common in most developing countries, being a challenge to the country's growth. Only $44 \%$ of family households have access to water suitable for consumption; $60 \%$ have access to sanitation, and $70 \%$ dump solid residues in the open air $^{(3)}$.

In this framework and having inherent factors of individual and family, environmental, occupational, economic, social, cultural and administrative order, there are undoubted challenges to health professionals, in general, and nurses specialized in community health.

Community health nursing develops a global practice focused on the community, having the responsibility to integrate the multidisciplinary team regarding the elaboration of the health diagnosis of a community, to subsequently implement intervention projects. Health diagnosis of a population points to the current situation - it creates a reference to the future and serves to guide health interventions, aiming to answer the population needs on prevention, disease control and health promotion.

Conducting a diagnosis of the health situation of a population allows us to understand it in depth, with reference to the present and, if possible, to the past, aiming to delineate the future. The latter guides actions to be developed, based on the problematization of the main dimensions of social reality and the corresponding mapping of needs.

Based on the diagnosis results, community intervention projects were carried out focusing on the health needs identified as priority, in the field of community health promotion.

This diagnosis aims to contribute for achievement of the objectives established by the National Plan for Health Development Plan (PNDS) 2012-2025 of "improving the health care provision with quality, in the aspects of promotion, prevention, treatment and rehabilitation, reinforcing the interaction between primary health care and hospital care"(2).

\section{OBJECTIVE}

To characterize the health situation of the population in the Imbondeiro neighborhood, sector C (Luanda).

\section{METHOD}

\section{Ethical aspects}

The health situation diagnosis is considered one of the specific competences of the Community Health Nurse Specialist. In this sense, the our health diagnosis was conducted in the Imbondeiro neighborhood (Luanda).

All subjects involved participated in a free and consent manner, with their anonymous identity protected. Individual information is confidential, and no harm resulted from this research, as referred to in the authorization opinion of this study, by the Chairman of the Board of Directors of the Multiperfil Clinic.

\section{Study design, location and period}

In the sphere of the internship in Community Health Nursing II, the response to this intent was given through the health diagnosis of the population living in the sector C, Imbondeiro neighborhood, Samba district, Luanda municipality, between April 24 and July 6 , 2017. This is a descriptive, cross-sectional and quantitative study.

\section{Population or sample; inclusion and exclusion criteria}

The target population of this study was the community living in the sector $\mathrm{C}$ of the Imbondeiro neighborhood, being considered as inclusion criteria for families: residing in the referred sector; accepting the participation in a free and clarified manner; and being in contact "door to door". The regulars of condominiums that belonged to companies allocated in the neighborhood were excluded.

\section{Study protocol}

The accidental sampling technique was used, and questionnaires adapted for the study population were used as data collection instruments, respecting the ethical principles of data collection and treatment. In this study, questionnaires were not target of pretests, because they had been previously applied in a community with similar characteristics; the ones used (four) consider general life conditions, and the specific conditions of each member of the family, according to age group. The concept of age group and all other concepts used in the questionnaires were defined according to the recommended by the World Health Organization.

\section{Results analysis and statistics}

In the results analysis, the descriptive statistics was applied with the statistical software SPPSS ${ }^{\circledast}$ version 21 . The questionnaires are available, after consulting the authors, to who intends on reapplying the study.

\section{RESULTS}

The sample had 1,321 people, with $46.02 \%$ males and $54.08 \%$ females; of this total, $42.62 \%$ are children, $15.14 \%$ are adolescents and $42.24 \%$ adults, constituting 341 family households. Considering data on total population of sector $\mathrm{C}$ 
is not available, it was not possible to calculate the percentage of the sample.

\section{Characterization of the general life conditions}

We found that the extended family $(51.9 \%)$ predominated, with an average of 5 individuals per family household, and $29.9 \%$ of households had more than six people.

Concerning dwellings, we verified that $40.5 \%$ of them had only one room, $65.4 \%$ had between one and two bedrooms and almost all (99.4\%) of dwellings had bathrooms. The family income $(71 \%)$ comes from the salary, its value $(32.8 \%)$ is situated between 20,000 to 50,000 kwanzas, with $40.5 \%$ of family households with incomes greater than 50,000 kwanzas. A total of $58.1 \%$ reside in houses of their own, $38.4 \%$ in rented houses and, of these, $66.41 \%$ had to pay rents between 7,000 and 25,000 kwanzas.

Of all participants of the sample, $98.9 \%$ used tank/cistern water, and $78 \%$ of families treated the water. Of these, $72.6 \%$ used household bleach and only $6.16 \%$ reported consuming mineral water.

Still on habitability conditions, $97.7 \%$ of dwellings have electrical energy from public network. Regarding the condition of dwellings, $59.53 \%$ had cracks, pests (cockroaches and rats) and moisture and mold in their interior.

Regarding comfort indicators, $77.4 \%$ have refrigerator and/or freezer. Of the families that answered the question "other comfort indicators", $92.7 \%$ had fans. Considering media, almost the totality $(93.5 \%$ ) had cellphones; $88 \%$, television sets and $19.4 \%$, internet.

Concerning domestic animals, the dog predominates in $30.2 \%$ of family households.

In the outdoor environment of dwellings, they are surrounded by dirt roads $(51.3 \%)$, paved roads $(45.5 \%)$, and $5.3 \%$ had stagnant water on the dwelling perimeter.

\section{Group characterization: children}

Of the total of children studied (563), 50.4\% are male and $49.6 \%$ are female, with a median age of 5 years, being the mode 3 years. Of the total, $52.2 \%$ attend school; of these, $87.1 \%$ attend the first cycle and $14.3 \%$ preschool education. Considering the adults, $76.6 \%$ of the children identified were taken care by relatives in the absence of parents, given that $13.5 \%$ stood alone at home without adult supervision.

Regarding the health surveillance of children, the Health Center is the resource most referred to by caregivers, having been used in the last year by $61.6 \%$ of children; of these, $41.5 \%$ had appointment with a nurse, $50.14 \%$ had medical appointment and only $8.64 \%$ reported having done it for vaccination and/or surveillance appointment.

In relation to the health history, $12.4 \%$ of the children total has suffered an accident, being the falls the most significant with $58.6 \%$ of accidents, followed by burns, with $20 \%$, and animal bites with $7.14 \%$.

Only $4.8 \%$ of children had oral surveillance and $36.8 \%$ brush the teeth twice a day.

About hand hygiene, $47.4 \%$ say to do it before meals and after using the toilet.
Regarding food consumption, $41.4 \%$ of the children drink milk every day. From the children up to 1 year of age, only $13.5 \%$ drink milk and $14.4 \%$ of children report never consuming milk or byproducts. With regard to the meat or fish consumption, $6.9 \%$ never consume it. Soup represents $22.6 \%$ of the food consumed; $12.8 \%$ never consume fruit and $20.8 \%$ never consume salad and vegetables. The ingestion of sugary foods is referred to by $55.2 \%$ of children, with candy ingestion at least three times a week, and $44.8 \%$ drink soft drinks at least three times a week. Among the participants, $92.6 \%$ consume some form of carbohydrates (rice, pasta, potatoes and funge ${ }^{1}$ ) at least three times a week.

In relation to leisure, from those who report playing, $47.3 \%$ have the habit of watching television; 10.3\% reading, and 7.6\% also practice sports, associated to games, as occupation of free times. In the case of children, $2.3 \%$ report sleeping less than 8 hours per day. The average hours of sleep are 10.24 hours, 20 hours being the maximum number of hours of sleep per day and 6 hours the minimum.

\section{Group characterization: adolescents}

In the sample of adolescent population, the female gender predominates with $52.5 \%$, being the median age 14.35 years and the mode, 15 years. Of these, $16.5 \%$ do not have mandatory complete education; $63.5 \%$ of respondents - regarding literacy - are in the first cycle; $96 \%$ of adolescents are students.

Considering their transportation, $63 \%$ walk on foot, $30 \%$ use public transportation and $1.5 \%$ ride the bike.

When they get sick, $18 \%$ of adolescents seek medical assistance in health institutions; of these, $43.85 \%$ seek Health Centers and $41.02 \%$, hospitals.

Of the total adolescent population, the most referred pathological situation is the respiratory condition, with $73.3 \%$. In the last year, $41 \%$ of adolescents stated having used health services, with $51.2 \%$ claiming to seek medical advice and $48.8 \%$ to nursing assistance.

In relation to sex life, $13.5 \%$ of this population report having active sex life started at or less than 15 years old and $13.7 \%$ claim to have started it at 11 years. From the adolescent population who have already started the sex life, $7.41 \%$ already have children, with the progenitor aged between 15 and 16 years. From the adolescent population with active sex life, $29.6 \%$ claim not using any contraceptive method, with $25.9 \%$ justifying this by lack of knowledge. Of adolescents who use contraception, all reported using condom.

Considering the oral health, only $3 \%$ of adolescents state making oral health surveillance, and 59.5\% brush their teeth according to the recommended.

In relation to hand hygiene habits, $10.5 \%$ do not have the habit of washing their hands.

In terms of food consumption, $30 \%$ of adolescents do not report eating soup, $19 \%$ do not ingest milk and/or byproducts. Of the total of adolescents of this study, $66 \%$ eat sweets three or more times a week, being relevant the fact that $54 \%$ do it on a daily basis. Ingestion of some form of carbohydrates (rice, pasta, potatoes and funge) is performed every day in $95 \%$ of adolescents.

1 Typical side dish in Angola; it consists of a paste made from cassava flour. 
As a form of leisure, adolescents report watching television and reading, with 62.5 and $56.5 \%$, respectively; $40.4 \%$ of adolescents practice sports at least once a week.

Considering the violence among them, $13.5 \%$ state to have been victims inside the school and $12.5 \%$ have been the aggressor; moreover, $2.5 \%$ state to have been assaulted by boyfriend/ girlfriend. Outside school, $22 \%$ report being victims and $15.5 \%$ aggressors, and $6.5 \%$ have been assaulted by boyfriend/girlfriend.

The falls and automobile accidents are the accidents most referred to by the adolescent population (42\%).

\section{Group characterization: adults}

A total of 558 adults participated in the study $-59 \%$ are females, being the median age 31.37 years, with a mode of 19 years. More than half of the sample (59.7\%) has literacy qualifications in the second cycle, being significant the fact that $18.92 \%$ of adults have no education at all.

Considering the employment status, $29.5 \%$ are unemployed $-32.4 \%$ in the primary sector, and $22.2 \%$ of adults are students.

Most of the population (67.6\%) uses public transportation and $18.8 \%$ walk on foot as the most used way of transportation.

Under the circumstance of health problems, 54\% claim "others" as a resource in the event of disease, being the Health Center the most used, with $55 \%$.

About $90 \%$ of the population over 18 years old do not have history of disease; of the adults remaining, hypertension is the most representative antecedent, with $79.4 \%$.

Adhesion to the therapeutic treatment is not verified in $17.05 \%$ of the respondents, being the cause of non-adhesion negligence $(40 \%)$ and lack of financial resources $(13.3 \%)$.

Of the total sample, $66.2 \%$ used the services of the Health Center in the last year, with $34.05 \%$ seek assistance from nurses and $64.05 \%$ from doctors. In the adult population sample, $48.1 \%$ use some contraceptive method, being the condom the most frequent method for $65.8 \%$. Of those who state not using contraception, as justification for not using these methods, they refer to lack of knowledge (59\%), not wanting to use (2.8\%), lack of interest $(2.8 \%)$, not having a boyfriend/girlfriend $(17.36 \%)$ and being in menopause $(7.29 \%)$.

Of the adult population sample, $3.2 \%$ have dependents; of these, $61.1 \%$ have partial dependence and $16.7 \%$ have total dependence. From those who have dependents, 55.6\% do not have any kind of support. From the $38.8 \%$ with some support, $57.14 \%$ receive it in terms of hygiene and comfort care.

Only $7 \%$ make oral health surveillance, $62.6 \%$ brush their teeth according to the recommended and $27.5 \%$ make it in the morning, at night and after meals.

Concerning hygiene habits, $5.7 \%$ of the adult sample do not have hand hygiene habits, and $94.6 \%$ of adults take from 6 to 8 baths a week.

Regarding eating habits, $94.3 \%$ ingest some form of carbohydrates (rice, pasta, potatoes and funge) every day, $37 \%$ eat processed meat (sausage and byproducts) three or more times a week, 34.4\% ingest sweets three or more times a week and $25.6 \%$ daily.

Considering the leisure time, the most indicated activities are watching TV and going to the church, with $47.6 \%$ and $30.2 \%$, respectively; $39.4 \%$ have other activities, such as resting $(28.18 \%)$, taking care of the house (28.18\%) and listening to music (12.27\%). Of the total, $28.4 \%$ practice sports at least once a week.

Concerning addictive behaviors, $4.3 \%$ of the adult population sample smokes, having started it after 18 years old; $38.1 \%$ drink alcohol, and, from these, $81.2 \%$ drink it at least one or two times a week, $13.6 \%$, between two and four times a week, and $4.2 \%$ more than four times a week.

Accidents were referred to by $46.5 \%$ of the sample of the adult population. Automobile accidents represent $53.85 \%$, followed by burns (14.23\%) and animal bites (12.21\%).

Regarding assaults suffered or inflicted, $27.4 \%$ were victims of aggression and $14.3 \%$ declared being the aggressors. Of the latter, $15.6 \%$ assaulted the partner; and of individuals victims of aggression, $14.1 \%$ were assaulted by the partner.

In this sample, $48.7 \%$ sleep from 8 to 9 hours; and $1.4 \%$ take some medication for sleeping disorder.

\section{DISCUSSION}

Based on the analysis conducted, our results can be compared with those presented by the National Statistics Institute (INE) of Angola ${ }^{(3)}$, in which the most representative age group is children, and the female gender.

Considering that investing in education is investing in development ${ }^{(4)}$, the number of adolescents that do not have complete mandatory education, as well as the quantity of unemployed adults in this sample is a matter of concern.

Countries that do not value education as a tool for nation development seem to have a fragile economy and population with low available income, which reflects on the well-being of the population, on the level of employment, habitability conditions and health determinants ${ }^{(5)}$.

The predominant family type is the extended one, with a mean of 5 individuals. In the absence of parents, children are mostly under the care of relatives, which may be related to the family typology and with low frequency of day-care centers and leisure centers, as well as with its high economic cost in Angola. We emphasize the fact that, in the absence of an adult, children stay at home alone, and there are risks associated with this practice.

Most residences have only one room and this interferes in the hygiene of spaces, privacy, ventilation and protection of family health, namely in terms of respiratory disease, which was verified to be frequent in the adolescent population. The fast urbanization process, which we can be observed in Angola, is an opportunity for these people and will undoubtedly contribute to the improvement of habitability conditions ${ }^{(6)}$.

Considering the sexual life of adolescents, we verify its early beginning, with lack of knowledge on contraception, which is manifested by unprotected sex. Among adults, about half of them refers to the use of contraceptives; and, when it is not used, the main reason is the lack of knowledge. Promotion of healthy behaviors using contraceptive methods promotes the improvement of maternal health, which is one of the evaluation indicators of development and quality of life of a country and its population. High maternal and neonatal mortality rates, as well as the high incidence level of HIV infection in the Angolan population ${ }^{(2)}$, are matters of concern that can be reduced with 
the increase of knowledge of the population considering the use of condoms.

We verify that one of the reasons for the non-adhesion to pharmacological treatment is the lack of economic resources.

Considering the food consumption, the habits are unbalanced, with excessive consumption of carbohydrates, processed meats and sweets, rather than fruits, salads and vegetables. Milk consumption is not a regular habit of all children, mainly in the age group up to 1 year. Sportive practice is present in all groups studied, but not in a regular manner. These associated factors may justify the presence of the chronic diseases most referenced in the questionnaires (hypertension).

Regarding addictive behaviors, the number of adults who report alcohol consumption is considerable and a matter of concern. It can be predictably related to the violence among adolescents or adults, either in the perspective of victims and aggressors ${ }^{(6-7)}$. In fact, the disturbance of the family balance, due to the abuse of addictive substances, such as alcohol, powered by the low income available, can lead to violent behaviors ${ }^{(8)}$.

Automobile accidents are the most frequent type in groups of adolescents and adults, corroborating the defined by the PNDS, as an indicator to be improved ${ }^{(2)}$.

\section{Study limitations}

The fact that it was not possible to have access to all families may have revealed only part of the relevant aspects. On the other hand, the fear of giving information, sometimes present in the non-verbal communication of participants, may have also prevented them to reveal some important issues related to their health and way of life.

\section{Contributions to the nursing field}

To know the way of life of a given population, as well as their health behaviors, allows a nursing intervention directed and adapted to the real needs of groups and populations. This intervention is a responsibility of the community health nurses, which, through the understanding of people's processes of life, design projects that allow to promote health and well-being.

\section{CONCLUSION}

Health planning is a fundamental tool to develop community health. It is only possible to develop intervention strategies when the health reality of a community is known. Such knowledge is performed by elaborating its diagnosis, which represents a specific element to specialized care and one of the competences of the community health nurse specialist.

Community nursing has a fundamental role, because professionals of this area have, par excellence, competences that allow them to appropriately respond to the needs of people, groups and communities, based on the multi-casual evaluation of the main health problems, continuing and developing intervention programs/projects, aiming at the empowering and exercise of citizenship.

The results obtained in the health situation diagnosis corroborate the exposed by the National Institute of Statistics of Angola, indicating a vast field of intervention from the conditions of habitability to the promotion of healthy living habits. Gender violence, child abandonment, alcohol consumption and sexually transmitted diseases represent, thus, the priority areas for intervention of community health nursing.

\section{REFERENCES}

1. Angola. Ministério da Saúde. Contribuição do sector de saúde para o plano nacional de desenvolvimento 2018-2022. Luanda: MS; 2016.

2. Angola. Ministério da Saúde. Plano Nacional de Desenvolvimento em Angola, 2012-2025.2. Luanda: MS; 2012.

3. Angola. Instituto Nacional de Estatística. Resultados definitivos do recenseamento geral da população e da habitação de Angola 2014. Luanda; INS; 2016.

4. Favaro N, Tumoro S. A relação entre educação e desenvolvimento econômico no capitalismo. Educ Soc[Internet]. $2016[$ cited 2017 Jan 05];37(135):557-71. Available from: http://www.scielo.br/pdf/es/v37n135/1678-4626-es-37-135-00557.pdf

5. Martins P, Cotta R, Siqueira-Batista R, Mendes F, Frachescinni S, Priore S, et al. Democracia e empoderamento no contexto da promoção da saúde: possibilidades e desafios apresentados ao programa de saúde da família. Physis[Internet]. 2010 [cited 2017 Jan 05];19(3):679-94.

6. AFDB, OECD \& UNDP. African Economic Outlook 2016: sustainable cities and structural transformation. OECD Publishing. 2016.

7. Duailibi R, Pinsky I. Álcool e violência: a psiquiatria e a saúde pública. Rev Bras Psiquiatr[Internet]. 2005[cited 2017 Jan 05];27(3):1767. Available from: http://www.scielo.br/pdf/rbp/v27n3/a04v27n3.pdf

8. Bes T, Lopes F, Morgan G, Ribeiro M, Duarte W. Relação da violência intrafamiliar e o uso abusivo de álcool ou entorpecentes na cidade de Pelotas, Rev AMRIGS[Internet]. 2013[cited 2017 Jan 05];57(1):9-13. Available from: http://www.amrigs.org.br/ revista/57-01/1108.pdf 